\title{
Identifikasi Cacing Gastrointestinal pada Babi di Kabupaten Jayawijaya dan Paniai, Provinsi Papua
} \author{
Paniai, Province of Papua \\ Isti Widayati $^{1)}$, Bernaddeta.W.I. Rahayu ${ }^{1)^{*}}$ dan Noak Degei ${ }^{2)}$ \\ ${ }^{1)}$ Laboratorium Produksi Ternak Fakultas Peternakan, Universitas Papua, \\ ${ }^{2)}$ Alumni Fakultas Peternakan, Universitas Papua, \\ Jl. Gunung Salju, Manokwari 98314, Indonesia
}

Identification of Gastrointestinal Worms in Pigs in the District of Jayawijaya and

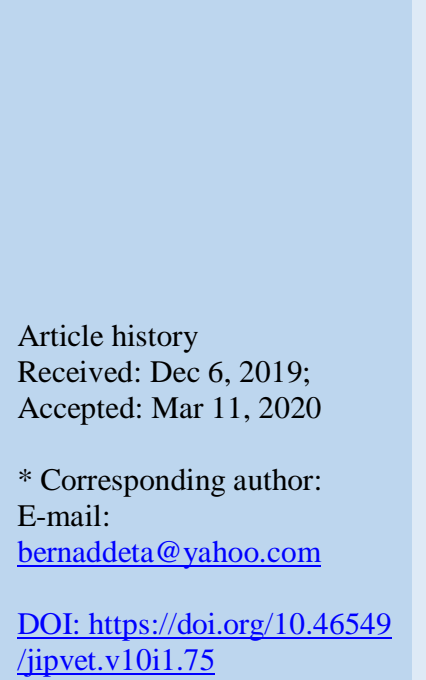

/iipvet.v10i1.75

\begin{abstract}
The rearing of pigs in the mountains of Papua is generally based on the freerange method during the daylight. Poor environmental sanitation and free-range management have been reported as risk factors of gastrointestinal worm infestation in pigs. In general, gastrointestinal parasite infestation can cause a loss of appetite, impede growth, decrease feed conversion rate, and increase vulnerabilities toward other pathogens. To add to that, the acute levels of infestation can cause death. Furthermore, some species can infest humans (zoonotic). As zoonotic parasites can impact the productivity and health of the people, it is crucial to identify the species of such parasites. This research was conducted in Umpakalo village at Kurulu district, Jayawijaya region, and three other villages namely Obaipugaida, Eyagitaida, and Ugituwataida at Ekadide district, Paniai region. Forty-five fecal samples from different pigs were used as the research material. The native method was used to identify the physical appearance of the eggs, and in turn, identify the species of the parasite. The data was analyzed in the tabulation form. The conclusion obtained in this research is that $95 \%$ of the fecal samples were infected by the gastrointestinal worms. Identified worms are Ascaris suum, Strongyloides ransomii, Trichuris suis, and Strongyle types. Most pigs have mixed infections.
\end{abstract}

Keywords: Parasites; Free range; Zoonotic; Gastrointestinal worm

\section{PENDAHULUAN}

Ternak babi bagi masyarakat asli Papua mempunyai peranan penting secara sosial budaya dan ekonomi, khusus di masyarakat daerah pegunungan seperti di Kabupaten Jaya Wijaya dan Paniai peranan tersebut masih sangat kuat. Di daerah ini umumnya babi masih dipelihara secara tradisional yaitu dibiarkan bebas berkeliaran pada pagi hingga sore hari dan dikandangkan pada malam hari, makanan diberikan dari sisa konsumsi keluarga dan ubiubian dalam jumlah yang kurang memadai dengan sanitasi kandang yang minim (Rahayu et al., 2012). Kondisi pemeliharaan ini memudahkan babi terserang penyakit salah satunya mudahnya penularan parasite dari ternak satu ke ternak yang lain. Beberapa spesies cacing dapat menular pada manusia atau zoonosis seperti Trichinella spp., Taenia solium, dan Aascaris lumbricoides/suum yang dapat membahayakan kesehatan manusia (Bendall et al., 2011; Supriadi et al., 2014; Setyani et al., 2018).

Beberapa faktor pemicu infeksi parasit adalah minimnya manejemen biosekuriti kandang, cekaman stres dan kekurangan nutrisi (Herjuno dan Purwaningsih, 2015). Salah satu parasit yang banyak menginfeksi adalah cacing gastrointestinal, yaitu cacing yang terdapat pada organ pencernaan. Cacing ini hampir menyerang semua ternak, Cacing gastrointestinal bagi babi sebagai inang definitif akan mengakibatkan penurunan produktivitas karena hilangnya nafsu makan, 
pengurangan kecepatan pertumbuhan, menurunnya konversi pakan dan meningkatnya kepekaan terhadap patogen lain (Yin, 2013).

Terkait dengan dampak terhadap produktifitas ternak babi dan kesehatan manusia maka perlu diketahui tingkat infeksi cacing gastrointestinal dan dilakukan identifikasi spesies cacing gastrointestinal pada babi di dua Kabupaten daerah Pegunungan Papua yakni Kabupaten Jayawijaya dan Paniai.

\section{MATERI DAN METODE}

Penelitian ini dilaksanakan di Kampung Umpakalo, Distrik Kurulu, Kabupaten Jayawijaya dan Kampung Obaipugaida, Eyagitaida dan Ugituwataida, Distrik Ekadide Kabupaten Paniai. Feses yang diperiksa adalah feses babi yang baru dikeluarkan dari babi umur 8 sampai 12 minggu. Babi yang diambil sampel fesesnya dipilih secara acak dengan jumlah 15 ekor dari Kabupaten Jayawiyaya dan 30 ekor dari Paniai. Pemeriksaan feses babi untuk identifikasi telur cacing secara kualitatif menggunakan metode natif seperti yang pernah dilakukan dalam penelitian (Purwaningsih dan Bambang, 2012), saat identifikasi telur cacing pada sampel feses pedet di Provinsi Jawa Tengah.

Variabel identifikasi telur cacing dilakukan berdasarkan hasil analisa telur cacing pada sampel feses babi dengan identifikasi berdasarkan pustaka. Data dianalisis secara tabulasi atau deskriptif.

\section{HASIL DAN PEMBAHASAN}

Sebanyak 45 sampel $(95 \%)$ positif terinfeksi cacing (nematoda) gastrointestinal.
Persentase keseluruhan ini lebih tinggi dibandingkan dengan hasil penelitian Permadani et al. (2012), yang menyatakan bahwa prevalensi cacing gastrointestinal babi di Papua pada Kabupaten Lembah Baliem dan Pegunungan Arfak sebesar 60\%. Perbedaan ini terjadi karena wilayah sampling, metode, dan sampel yang diperiksa berbeda. Pada penelitian ini sampel yang diperiksa adalah feses untuk mengidentifikasi telur cacing saluran gastrointestinal yang ada pada feses babi, sedangkan penelitian Permadani et al. (2012), sampel yang diperiksa hanya organ lambung dari hasil nekropsi babi. Perbedaan prevalensi infeksi nematoda pada usus halus babi dilaporkan juga oleh Guna et al. (2014), bahwa prevalensi nematoda gastrointestinal babi di Lembah Baliem dan Pegunungan Arfak Papua sebesar 57\%. Hal ini juga dikarenakan wilayah sampling dan sampel yang berbeda. Guna et al. (2014), menggunakan sampel usus sehingga yang diidentifikasi adalah cacing dewasa. Hasil penelitian ini bahkan lebih tinggi dibandingkan hasil penelitian Fendriyanto et al. (2015), yang menemukan bahwa prevalensi nematoda gastrointestinal babi di Bali sebesar 71,6\%. Berdasarkan hasil pemeriksaan sampel feses dengan metode natif, jenis telur cacing yang ditemukan adalah hanya dari kelas nematoda yaitu Ascaris suum, Strongyloides ransomi, Trichuris suis, dan telur cacing tipe Strongyle (Tabel 1). Parasit gastrointestinal babi selain nematoda, dapat ditemukan juga protozoa balantidium, cacing Acanthocephala Macracantorynchus hirudinaseus, dan cacing golongan cestoda Permadani et al. (2012), Guna et al. (2014), dan Fendriyanto et al. (2015).

Tabel 1.Telur cacing nematoda gastrointestinal yang ditemukan

\begin{tabular}{lcccc}
\multicolumn{1}{c}{ Kampung } & Ascaris suum & Strongyloides ransomi & Trichuris suis & TipeStrongyle \\
Obaipugaida & $\sqrt{ }$ & $\sqrt{ }$ & $\sqrt{ }$ & $\sqrt{ }$ \\
Eyagitaida & $\sqrt{ }$ & $\sqrt{ }$ & $\sqrt{ }$ & $\sqrt{ }$ \\
Ugituwataida & $\sqrt{ }$ & $\sqrt{ }$ & $\sqrt{ }$ & $\sqrt{ }$ \\
Umpakalo & $\sqrt{ }$ & - &
\end{tabular}

Morfologi telur cacing nematoda gastrointestinal babi yang ditemukan dalam penelitian ini dapat dilihat pada Gambar 1. 


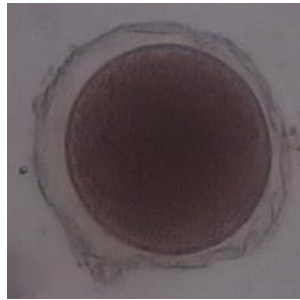

$\mathrm{a}$

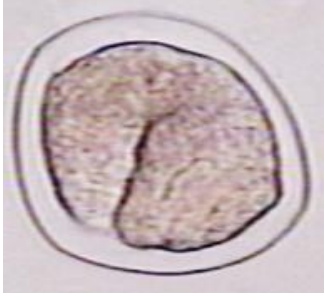

b

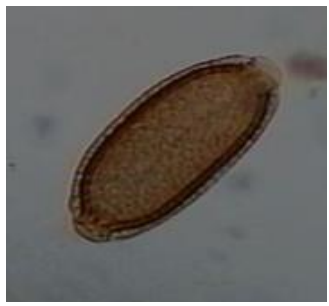

c

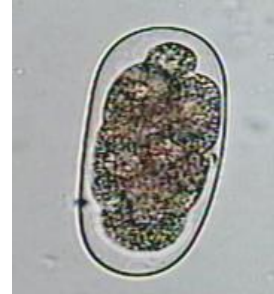

d

Gambar 1. Morfologi telur cacing nematoda gastrointestinal babi (perbesaran mikroskop 400x)

a) Telur cacing Ascaris suum; b) Telur cacing Strongyloides ransomi; c) Telur cacing Trichuris suis;d)Telur cacing tipe Strongyl

Morfologi telur cacing Ascaris yang diidentifikasi dari sampel feses babi dalam penelitian ini dapat dilihat pada (Gambar 1a.) yang diidentifikasi sebagai telur cacing Ascaris suum. Hal ini sesuai dengan Levine (1994), yang menyampaikan bahwa spesies cacing Ascaris yang menginfeksi pada babi umumnya adalah spesies Ascaris suum. Pada manusia umumnya disebabkan oleh Ascaris lumbricoides, sedangkan pada anjing kucing disebabkan oleh Toxocara canis dan Toxocara cati. Morfologi telur cacing Ascaris suum pada babi berbeda dengan telur cacing dari kelas nematoda yang lainnya. Menurut Soedarto (2012), telur cacing Ascaris suum mirip dengan telur cacing Toxocara yaitu berbentuk oval dengan permukaan yang bergerigi kecil, berwarna cokelat muda dan berdinding tebal. Matsubayashi et al (2009) menyatakan telur cacing Ascaris suum memiliki bentuk oval pendek, permukaan bergerigi, panjang 50-70 x 40-50 mikron, berwarna kuning kecoklatan karena lapisan protein pada dinding telur cacing menyerap zat warna empedu. Terkadang dijumpai telur cacing Ascaris suum yang kehilangan lapisan protein pada dinding telur sehingga telur cacing menjadi tidak berwarna dan menyulitkan identifikasi. Menurut Matsubayashi et al (2009), Levine (1994), dan Soedarto (2012), Ascaris suum umum ditemukan menginfeksi pada babi dan bersifat zoonosis (dapat menular pada manusia).

Morfologi telur cacing Strongyloides yang ditemukan pada babi dalam penelitian ini dapat dilihat pada (Gambar 1b). Strongyloides yang umum menginfeksi babi adalah spesies Strongyloides ransomi memiliki telur dengan ciri morfologi berbentuk elips atau lonjong, dinding telur tipis dan terdapat embrio larva cacing di dalam telur, ukuran telur 45-55 x 2635 mikron (Levine, 1994).

Morfologi telur cacing Trichuris yang ditemukan pada babi dalam penelitian ini dapat dilihat pada (Gambar 1c). Cacing Trichuris yang umum menginfeksi pada babi adalah spesies Trichuris suis dengan ciri telur berwarna kecoklatan, memiliki bentuk seperti tempayan pada kedua kutubnya terdapat operkulum yaitu semacam penutup atau sumbat yang jernih dan menonjol. Dinding telur tebal terdiri atas dua lapis, bagian dalam jernih dan bagian luar berwarna kecoklatan.Telur cacing belum bersegmen ketika dikeluarkan, ukurantelur 50-56 x 21-25 mikron. Morfologi telur cacing Trichuris suis pada babi dan Trichuris trichiura pada manusia sangat mirip sehingga sulit dibedakan (Levine, 1994). Morfologi telur cacing Trichuris suis dan Trichuris trichiura juga mirip dengan telur cacing Capillaria hepatica yang sering menginfeksi hewan rodensia (Makimian dan Robby, 1996).

Morfologi telur cacing tipe strongyle yang ditemukan pada babi di ketiga kampung dapat dilihat pada (Gambar 1d). Telur cacing tipe Strongyle (Strongyloid) menurut Lee (2012), merupakan golongan telur cacing yang memiliki morfologi yang sangat mirip sehingga sulit dibedakan. Cacing gastrointestinal babi yang memiliki telur mirip adalah spesies Oesophagostomum sp. dan Hyostrongylus sp. sehingga telur cacing keduanya disebut sebagai telur cacing tipe Strongyle. Bentuk telur tipe strongyle lonjong dan terdapat segmen embrio di dalam telur.

Jumlah babi yang terinfeksi/menderita jenis cacing yang ditemukan dapat dilihat pada Tabel 2. Babi di Kampung Ugituwataida umumnya terifeksi cacing jenis Strongyle dan 
Strongyloides ransomi. Cacing Trichuris suis terbanyak menginfeksi babi di Kampung
Eyagitaida dan cacing Ascaris suum terbanyak menginfeksi di Kampung Obaipugaida.

Tabel 2. Jumlah sampel feses babi yang terinfeksi/menderita jenis cacing yang ditemukan

\begin{tabular}{lcccc}
\multicolumn{1}{c}{ Kampung } & $\begin{array}{c}\text { Ascarissuum } \\
\text { (ekor babi) }\end{array}$ & $\begin{array}{c}\text { Strongyloidesransomi } \\
\text { (ekor babi) }\end{array}$ & $\begin{array}{c}\text { Trichurissuis } \\
\text { (ekor babi) }\end{array}$ & $\begin{array}{c}\text { TipeStrongyle } \\
\text { (ekor babi) }\end{array}$ \\
Obaipugaida & 5 & 2 & 4 & 6 \\
Eyagitaida & 1 & 2 & 8 & 7 \\
Ugituwataida & 1 & 5 & 7 & 9 \\
Umpakalo & 4 & - & 6 & 4 \\
Jumlah & 11 & 9 & 29 & 26
\end{tabular}

Spesies cacing gastrointestinal yang ditemukan dalam penelitian ini sesuai dengan Guna et al. (2014), bahwa nematoda gastrointestinal yang ditemukan menginfeksi babi di Lembah Baliem dan Pegunungan Arfak Papua, antara lain Ascaris suum, Strongyloides ransomi, Globocephalus urosubulatus, dan cacing dari golongan Acanthocephala yaitu Macracanthorhynchus hirudinaceus. Hasil penelitian di luar Papua menyebutkan bahwa sebesar $60 \%$ cacing yang menginfeksi babi di Bali adalah tipe Strongyle (Agustina, 2013) dan prevalensi di Makassar sebanyak 2\% (Inriani, 2015).

Jenis infeksi nematode yang sama di ketiga kampung di Distrik Ekadide dan di Kampung Umpakalo Distrik Kurulu diyakini disebabkan oleh sistem pemeliharaan yang sama, yaitu babi dibiarkan berkeliaran (tidak dikandangkan) dan bahwa kondisi iklim di daerah-daerah tersebut relative sama. Pada manusia Cacing Ascaris lumbricoides, Strongyloides stercoralis dan Trichuris trichiura termasuk pada golongan soil transmited helminths (STHs) yaitu cacing yang sebagian siklus hidupnya berada di tanah dan mempunyai peluang menular ke manusia melalui tanah terutama cacing Ascaris yang zoonosis. Ketiga cacing di atas umumnya hidup di daerah tropis dan subtropis (De Silva et al., 2003).

Pemeliharaan babi di daerah perkampungan Papua termasuk di Kabupaten Paniai dan Jayawijaya umumnya dipelihara secara dilepas. Saat dilepas babi mencungkil tanah menggunakan mulutnya dan memakan cacing atau rumput-rumputan dan secara tidak sengaja babi juga menelan telur cacing. Secara umum ketiga jenis cacing yang diidentifikasi pada lokasi penelitian mempunyai siklus yang sama yaitu: cacing betina dewasa akan bertelur dan dikeluarkan bersama feses di tanah. Menurut Irianto (2009) disitasi Hernasari (2011), Pada kondisi lingkungan yang kondusif seperti kelembaban tinggi, maka telur cacing akan berkembang menjadi fase infektif (berembrio), yang jika tertelan oleh babi maka akan masuk di saluran pencernaan, menetas dan menjadi dewasa). Seperti dikemukakan oleh Levine (1994), bahwa penularan nematoda gastrointestinal pada babi adalah karena memakan larva cacing stadium infektif yang terdapat pada makanan atau air minum yang tercemar feses babi.

Jenis infeksi yang ditemukan pada penelitian ini adalah infeksi campuran, yaitu seekor individu babi terinfeksi oleh lebih dari 1 jenis cacing gastrointestinal (Tabel 3). Infeksi campuran lebih banyak terjadi dibanding infeksi tunggal. Tamboura et al. (2006), melaporkan bahwa babi dapat terinfeksi endoparasit tunggal dan campuran hingga empat jenis parasit berbeda. Infeksi campuran dapat disebabkan karena sistem pemeliharaan ternak babi yang masih diumbar. Sistem pemeliharaan ini sangat berpotensi bagi endoparasit untuk menginfeksi babi. Hasil penelitian Tamboura et al. (2006) dan Sirojuddin (2018), sesuai dengan hasil penelitian ini bahwa sistem pemeliharaan di keempat kampung (Obaipugaida, Eyagitaida, Ugituwataida, dan Umpakalo) Kabupaten Paniai dan Jayawijaya masih dibiarkan berkeliaran (diumbar) sehingga dapat menyebabkan terjadinya infeksi campuran cacing gastrointestinal pada babi. 
Tabel 3. Jumlah babi yang mengalami infeksi tunggal dan campuran

\begin{tabular}{lccc}
\multicolumn{1}{c}{ Kampung } & 1 spesies & 2 spesies & 3 spesies \\
Obaipugaida & $40 \%$ & $50 \%$ & $10 \%$ \\
Eyagitaida & $20 \%$ & $50 \%$ & $20 \%$ \\
Ugituwataida & $20 \%$ & $40 \%$ & $40 \%$ \\
Umpakalo & $13 \%$ & $47 \%$ & $33 \%$
\end{tabular}

\section{KESIMPULAN}

Berdasarkan penelitian ini diperoleh kesimpulan bahwa persentase infeksi parasit gastrointestinal pada babi sangat tinggi. Di Kabupaten Jayawijaya dan Paniai, jenis telur cacing yang ditemukan tidak berbeda yaitu : Ascaris suum, Strongyloides ransomi, Trichuris suis dan tipe Strongyle. Sebagian besar babi mengalami infeksi campuran karena ditemukan lebih dari satu jenis telur cacing pada feses.

\section{DAFTAR PUSTAKA}

Agustina. 2013. Identifikasi dan Prevalensi Cacing Tipe Strongyle Pada Babi. Buletin Fakultas Kedokteran Hewan Universitas Udayana. Bali.

Bendall RP, Maggie B, Martha B, J. Russell S, dan Peter N. 2011. Zoonotic Ascariasis. United Kingdom. Emerg Infect Dis.17(10).

De Silva NR, Brooker S, Hotez PZ, Montresor A, Engels D, Savioli L. 2003. Soil Transmitted Helminth Infections: Uupdating the Global Picture. Trends Parasitol. 19 (12): 547-51.

De-Ming Yin, Fen Li, Xi-Jun Wang, Yuan Lin, Zeng-Zai Liu, Ning-Bo Xia, Xiao-Feng Sheng, Ting Wang, Yi Liu and Wei Liu, 2013. Prevalence of Helminths in Adult Pigs in Hunan Province, China. Journal of Animal and Veterinary Advances, 12: 1123-1125.

Fendriyanto, A., Oka, I., \& Agustina, K. (2015). Identifikasi dan Prevalensi Cacing Nematoda Saluran Pencernaan pada Anak Babi di Bali. Indonesia Medicus Veterinus. 4(5) : 465-473 Retrieved from https://ojs.unud.ac.id/index.php/imv/ article/view/17563

Guna, I, Suratma, N, \& Damriyasa, I. 2014. Infeksi Cacing Nematoda Pada Usus Halus Babi di Lembah Baliem dan Pegunungan Arfak Papua. Buletin Veteriner Udayana. Vol. 6 No 2. Hal 129 - 134
Herjuno A N dan Purwaningsih E. 2015. Nematoda Parasit Gastrointestinal pada Satwa Mamalia di Penangkaran Pusat Penelitian Biologi LIPI Cibinong. Jawa Barat. Prosiding Seminar Nasional Masyarakat Biodiversity Indonesia. ISSN: 2407-8050. 8 Desember 2015. 1 (8): 17851789.

Hernasari PR. 2011. Identifikasi Endoparasit Pada Sampel Feses Nasalis larvatus, Presbytis comata, Presbytis coamata dan Presbytis siamensis dalam Penangkaran Menggunakan Metode Natif dan Pengapungan dengan Sentrifuge. Skripsi Sarjana. Fakultas Matematika dan Ilmu Pengetahuan.Departemen Biologi Universitas Indonesia. Jakarta.

Inriani N. 2015. Identifikasi Cacing Nematoda Pada Saluran Pencernaan Babi. Skripsi Sarjana Kedokteran Hewan. Fakultas Kedokteran Universitas Hasanuddin. Makassar.

Lee A. 2012. Internal Parasite of Pigs. Primefact 1149 Departemen Of Primary Industries. NSW Goverment.

Levine ND. 1994. Parasitologi Veteriner. Diterjemahkan oleh Ashadi G. Dari Textbook of Veterinary Parasitology. Gadjah Mada University Press.Yogyakarta. Hal 190-223.

Makimian dan Robby. 1996. Diagnostik Parasitologi Kedokteran. EGC. Jakarta.

Matsubayashi, Makoto \& Kita, Toshimasa \& Narushima, Tsuguto \& Kimata, Isao \& Tani, Hiroyuki \& Sasai, Kazumi \& Baba, Evren. (2009). Coprological Survey of Parasitic Infections in Pigs and Cattle in Slaughterhouse in Osaka, Japan. The Journal of veterinary medical science / the Japanese Society of Veterinary Science. 71. 1079-83. DOI: 10.1292/jvms.71.1079

Permadani, i., Adi Suratma, N., \& Damriyasa, I. 2013. Prevalensi Cacing Nematoda pada Babi. Indonesia Medicus Veterinus, 
Retrieved from https://ojs.unud.ac.id/index.php/imv/articl e/view/4417

Purwaningsih., Bambang S. 2012. Prevalensi Helminthiasis pada Saluran Pencernaan Pedet di Provinsi Jawa Tengah. Jurnal Ilmu Peternakan Dan Veteriner Tropis (Journal of Tropical Animal And Veterinary Science), 7(1), $11-15$. doi:10.30862/jipvet.v7i1.38

Rahayu BWI, Dwi N, dan Iriani S. 2012. Limbah Buah Merah (Pandanus Conaideus Lam) Dalam Meningkatkan Pertumbuhan Dan Status Kesehatan Babi di Kampung Umpakalo (Pemekaran Kampung Waga-Waga) Kabupaten Jayawijaya. Fakultas Peternakan dan Ilmu Kelautan Universitas Negeri Papua. Manokwari. Laporan Kemajuan Penelitian Hibah Bersaing Dikti.

Setyani E, Fadjar S, Etih S. 2018. Seroprevalensi Trichinellosis pada Ternak Babi di Wilayah Kabupaten Tangerang.
Provinsi Banten. Veteriner. 19 (2) : 269275.

Sirojuddin Muhammad Taufiq. 2018. Infeksi Nematoda Gastrointestinal Pada Babi Di Kecamatan Lindu. Kabupaten Sigi. Sulawesi Tengah. Skripsi. FKH. IPB.

Soedarto. 2012. Penyakit Zoonosis Manusia Ditularkan Oleh Hewan. Human Zoonosis Diseases. Sagung Seto.

Supriadi, Muslihin A. Rusmanto B. 2014. PreEliminasi Parasit Gastrointestinal pada Babi dari Desa Suranadi Kecamatan Narmada Lombok Barat. Media Bina Ilmiah. ISSN 1978-3787. 8 (5): 64-68.

Tamboura HH, Banga Mboko H, Maes D, Youssao I, Traore A, Bayala B, and Dembele MA, 2006. Prevalence of Common Gastrointestinal Nematode Parasites in Scavenging Pigs of Different Ages and Sexes in Eastern Centre Province, Burkina Faso, Onderstepoort Journal of Veterinary Research, 75:53-60 